\title{
Phase Equilibria and some Properties of Solid Solutions in The $\mathrm{Tl}_{5} \mathrm{Te}_{3}-\mathrm{Tl}_{9} \mathrm{SbTe}_{6}-\mathrm{Tl}_{9} \mathrm{GdTe}_{6}$ System
}

\author{
Samira Zakir Imamaliyeva, ${ }^{* 1}$ Turan Mirzaly Gasanly, ${ }^{2}$ Vagif Akber Gasymov ${ }^{1}$ \\ and Mahammad Baba Babanly \\ ${ }^{1}$ Institute of Catalysis and Inorganic Chemistry named after acad.M.Nagiyev, \\ Azerbaijan National Academy of Sciences, H.Javid ave., 131, Az-1143, Baku, Azerbaijan \\ ${ }^{2}$ Baku State University, Z.Khalilov str., 23, Az-1148, Baku, Azerbaijan \\ *Corresponding author: E-mail: samira9597a@gmail.com
}

Received: 15-01-2017

\begin{abstract}
Phase equilibria in the $\mathrm{Tl}_{5} \mathrm{Te}_{3}-\mathrm{Tl}_{9} \mathrm{SbTe}_{6}-\mathrm{Tl}_{9} \mathrm{GdTe}_{6}$ system were experimentally studied by thermal analysis, X-ray diffraction and microhardness measurements applied to equilibrated alloys. Some isopleth sections, isothermal section at $760 \mathrm{~K}$, and also projections of the liquidus and solidus surfaces, were constructed. A continuous series of solid solutions was found in this system. Solid solutions crystallize in the tetragonal $\mathrm{Tl}_{5} \mathrm{Te}_{3}$ structure type.
\end{abstract}

Keywords: Thallium-antimony tellurides; thallium-gadolinium tellurides; phase equilibria; projections of the liquidus and solidus; solid solutions; crystal structure

\section{Introduction}

A number of works have illustrated the continuing interests in new multinary chalcogenides of heavy p-elements, including rare earth elements. Due to their important functional properties, they find applications in a wide range of devices such as ion-selective sensors, microbatteries, modern day solar cells, and thermoelectric energy conversion. ${ }^{1-3}$ Moreover; some of them have attracted interest as topological insulators. ${ }^{4,5}$

Thallium subtelluride, $\mathrm{Tl}_{5} \mathrm{Te}_{3}$, thanks to features of crystal structure (Sp.gr.I4/mcm, $a=8.930 ; c=12.598 \AA$ ) has a number of ternary derivatives of $\mathrm{Tl}_{4} \mathrm{~A}^{\mathrm{IV}} \mathrm{Te}_{3}$ and $\mathrm{Tl}_{9} \mathrm{~B}^{\mathrm{V}} \mathrm{Te}_{6}$-type $\left(\mathrm{A}^{\mathrm{IV}}-\mathrm{Sn}, \mathrm{Pb} ; \mathrm{B}^{\mathrm{V}}-\mathrm{Sb}, \mathrm{Bi}\right){ }^{6-9}$ These compounds exhibit good thermoelectric properties, and $\mathrm{Tl}_{9} \mathrm{Bi}$ $\mathrm{Te}_{6}$ has reported a ZT $\sim 1.2$ at $500 \mathrm{~K}^{10-12}$ Furthermore, the Dirac-like surface states were observed in $\left[\mathrm{Tl}_{4}\right] \mathrm{TlTe}_{3}$ $\left(\mathrm{Tl}_{5} \mathrm{Te}_{3}\right)$ and its tin-doped derivative $\left[\mathrm{Tl}_{4}\right]\left(\mathrm{Tl}_{1-\mathrm{x}} \mathrm{Sn}_{\mathrm{x}}\right) \mathrm{Te}_{3}{ }^{13}$

The new ternary compounds of $\mathrm{Tl}_{9} \mathrm{LnTe}_{6}$ - type (Ln-Ce, Nd, Sm, Gd, Tm, Tb) which are a new of substitution derivatives of $\mathrm{Tl}_{5} \mathrm{Te}_{3}$ were reported in some wokrs. ${ }^{14-16}$ Later, H.Kleinke and co-workers have reported the crystal structure as well as magnetic and thermoelectric properties for a number of $\mathrm{Tl}_{9} \mathrm{LnTe}_{6}$-type compounds. ${ }^{17-19}$
Further studies of phase equilibria in the systems including the $\mathrm{Tl}_{5} \mathrm{Te}_{3}$ compound or its structural analogs showed that these systems are characterized by the formation of unlimited solid solutions. ${ }^{20-22}$

This study reports a detailed investigation of phase equilibria in the $\mathrm{Tl}_{5} \mathrm{Te}_{3}-\mathrm{Tl}_{9} \mathrm{SbTe}_{6}-\mathrm{Tl}_{9} \mathrm{GdTe}_{6}$ system.

$\mathrm{Tl}_{5} \mathrm{Te}_{3}$ and $\mathrm{Tl}_{9} \mathrm{SbTe}_{6}$ melt congruently at 723 and 790 $\mathrm{K}$ while $\mathrm{Tl}_{9} \mathrm{GdTe}_{6}$ melts with decomposition by the peritectic reaction at $800 \mathrm{~K}^{7,}{ }^{73,24}$ The lattice parameters of $\mathrm{Tl}_{9} \mathrm{SbTe}_{6}$ and $\mathrm{Tl}_{9} \mathrm{GdTe}_{6}$ are following: $a=8.829, c=$ 13.001 $\AA, \mathrm{z}=2 ; a=8.870 ; c=13.027 \AA, \mathrm{z}=2 .{ }^{24,25}$

The $\mathrm{Tl}_{5} \mathrm{Te}_{3}-\mathrm{Tl}_{9} \mathrm{SbTe}_{6}$ system is characterized by the formation of continuous solid solutions areas based on $\mathrm{Tl}_{5} \mathrm{Te}_{3}{ }^{7}$

\section{Experimental}

\section{1. Materials and Syntheses}

For the synthesis, we used the high purity thallium, antimony, gadolinium, and tellurium (the purity of the ingredient was better than 99.99 mass. \%).

The surface of thallium was coated by a thin oxide film, which was removed before use. 
It should be noted that, thallium and its compounds are extremely toxic, and should be handled with great care. Thallium is readily absorbed through the skin and care should be taken to avoid this route of exposure. Therefore, we used protective gloves at all times when working with thallium. However, no respiratory tract covers are required since thallium is not volatile.

The elements were weighed to be about $10 \mathrm{~g}$ in total according to the molar ratio of the corresponding binary and ternary compound, were placed in silica tubes of about $20 \mathrm{~cm}$ in length and then were sealed under a vacuum of $10^{-2} \mathrm{~Pa}$.

Taking into account the congruent melting of $\mathrm{Tl}_{5} \mathrm{Te}_{3}$ and $\mathrm{Tl}_{9} \mathrm{SbTe}_{6}$, their synthesis was carried out by heating of elements in one zone electric furnace at the 750 and $830 \mathrm{~K}$, respectively followed by cooling in the switchedoff furnace.

The obtained intermediate ingot of $\mathrm{Tl}_{9} \mathrm{GdTe}_{6}$ was carefully ground in an agate mortar, pressed into the circular pellet of about $10 \mathrm{~mm}$ diameter and annealed at $770 \mathrm{~K}$ within $\sim 1000 \mathrm{~h}$ as it was done in previous work. ${ }^{24}$ The weight losses during the pellet preparation were less than 0.5 mass. \%. In order to prevent a reaction between the gadolinium and the quartz during high temperature reactions, quartz tubes coated internally with a thin layer of carbon were used.

The purity of the synthesized compounds was checked by the X-ray diffraction (XRD) and differential thermal analysis (DTA).

Only one thermal effect was observed for $\mathrm{Tl}_{5} \mathrm{Te}_{3}$ $(723 \mathrm{~K})$ and $\mathrm{Tl}_{9} \mathrm{SbTe}_{6}(790 \mathrm{~K})$; whereas two peaks for $\mathrm{Tl}_{9} \mathrm{GdTe}_{6}$ which were relevant the peritectic reaction at $800 \mathrm{~K}$ and its liquidus at $1190 \mathrm{~K}$. These data are in good agreement with the literature references. ${ }^{7,23,24}$

XRD confirmed that synthesized compounds were phase-pure. Powder XRD pattern of the $\mathrm{Tl}_{9} \mathrm{SbTe}_{6}$ and $\mathrm{Tl}_{9} \mathrm{GdTe}_{6}$ were similar to that of $\mathrm{Tl}_{5} \mathrm{Te}_{3}$. The unit cell parameters were practically equal to literature data (Table 1)..$^{24,25}$

Synthesized binary and ternary compounds were used for the fabrication of the alloys of the $\mathrm{Tl}_{5} \mathrm{Te}_{3}-\mathrm{Tl}_{9} \mathrm{Sb}$ $\mathrm{Te}_{6}-\mathrm{Tl}_{9} \mathrm{GdTe}_{6}$ system. The alloys weighing $1 \mathrm{~g}$ were synthesized in quartz tube evacuated to $10^{-2} \mathrm{~Pa}$. Taking into account the fact that an equilibrium state could not be obtained even after the long-time $(1000 \mathrm{~h})$ annealing, after synthesis the samples containing more than $60 \mathrm{~mol} \%$ $\mathrm{Tl}_{9} \mathrm{GdTe}_{6}$ were powdered, mixed, pressed into circular pellets of about $10 \mathrm{~mm}$ diameter and annealed at $700 \mathrm{~K}$ for 1 month.

\section{2. Methods}

$\mathrm{X}$-ray powder diffraction (XRD), differential thermal analysis (DTA) and also microhardness measurements were employed to check the purity of the synthesized starting compounds and analyze the samples in order to plot the phase diagrams.
DTA was performed using a NETZSCH $404 \mathrm{~F} 1 \mathrm{Pe}-$ gasus differential scanning calorimeter within room temperature and $\sim 1400 \mathrm{~K}$ depending on the composition of the alloys at a heating rate of $10 \mathrm{~K} \mathrm{~min}^{-1}$ and accuracy about $\pm 3^{\circ}$. Temperatures of thermal effects were taken mainly from the heating curves.

The XRD measurements of the powdered specimen were recorded using a Bruker D8 diffractometer utilizing $\mathrm{CuK}_{\alpha}$ radiation within $2 \theta=10 \div 70^{\circ}$. The unit cell parameters were calculated by indexing of powder patterns using Topas V3.0 software. An accuracy of the crystal lattice parameters is shown in parentheses (Table).

Microhardness measurements were done with a microhardnesmeter PMT-3, the typical loading being $20 \mathrm{~g}$ and accuracy about $20 \mathrm{MPa}$.

\section{Results and Discussion}

The combined analysis of obtained experimental and literature data $[7,24,25]$ allowed us to construct the diagram of the phase equilibria in the $\mathrm{Tl}_{5} \mathrm{Te}_{3}-\mathrm{Tl}_{9} \mathrm{SbTe}_{6}$ $\mathrm{Tl}_{9} \mathrm{GdTe}_{6}$ system (Table, Fig.1-6).

The $2 \mathrm{Tl}_{5} \mathrm{Te}_{3}-\mathrm{Tl}_{9} \mathrm{SbTe}_{6}$ system is quasi-binary and characterized by the formation of unlimited solid solutions $(\delta)$ with $\mathrm{Tl}_{5} \mathrm{Te}_{3}$-structure. ${ }^{7}$

The $2 \mathrm{Tl}_{5} \mathrm{Te}_{3}-\mathrm{Tl}_{9} \mathrm{GdTe}_{6}$ and $\mathrm{Tl}_{9} \mathrm{SbTe}_{6}-\mathrm{Tl}_{9} \mathrm{GdTe}_{6}$ systems (Table 1, Figs. 1a, 2a) are characterized by the formation of continuous solid solutions $(\delta)$ with $\mathrm{Tl}_{5} \mathrm{Te}_{3}$-structure. However, they are non-quasi-binary sections of the Tl-Gd-Te ternary and Tl-Sb-Gd-Te quaternary systems due to the peritectic melting of the $\mathrm{Tl}_{9} \mathrm{GdTe}_{6}$ compound. This leads to crystallization infusible $X$ phase in a wide composition interval and formation two-phase $\mathrm{L}+\mathrm{X}$ and three-phase $\mathrm{L}+\mathrm{X}+\delta$ areas. These areas are not experimentally fixed due to narrow temperature interval and shown by dotted line.

We have assumed that the $\mathrm{X}$ phase has a composition $\mathrm{TlGdTe}_{2}$. This assumption is confirmed by the presence of the most intense reflection peaks of $\mathrm{TlGdTe}_{2}$ on diffractograms of the as-cast alloys from the region more than $63 \mathrm{~mol} \% \mathrm{Tl}_{9} \mathrm{GdTe}_{6}{ }^{26}$

It should be noted that regardless a very close melting temperature of $\mathrm{Tl}_{9} \mathrm{SbTe}_{6}(790 \mathrm{~K})$ and peritectic decomposition of $\mathrm{Tl}_{9} \mathrm{GdTe}_{6}(800 \mathrm{~K})$ compounds, the liquidus and solidus curves have not extremum points and temperature interval of the crystallization of the $\delta$-phase is less than $3 \mathrm{~K}$. Such phenomenon is realized when the enthalpy of mixing during the formation of solid and liquid solutions from starting compounds is practically equal to zero. In other words, in the studied system the $\mathrm{Sb} \rightarrow \mathrm{Gd}$ replacement in the solid and liquid states are not accompanied by a significant thermal effect. This fact allows us to characterize the $\delta$-solid solutions as quasi-ideal solution. 
Table 1. Some properties of phases in the $\mathrm{Tl}_{5} \mathrm{Te}_{3}-\mathrm{Tl}_{9} \mathrm{SbTe}_{6}-\mathrm{Tl}_{9} \mathrm{GdTe}_{6}$ system.

\begin{tabular}{|c|c|c|c|c|}
\hline \multirow[t]{2}{*}{ Phase } & \multirow{2}{*}{$\begin{array}{l}\text { Thermal effects, } \\
\text { K } \\
\text { (accuracy } \pm 3^{\circ} \text { ) }\end{array}$} & \multirow{2}{*}{$\begin{array}{c}\text { Microhardness, } \\
\text { MPa, } \\
\text { (accuracy } \pm 20 \text { MPa) }\end{array}$} & \multicolumn{2}{|c|}{$\begin{array}{c}\text { Parameters of } \\
\text { tetragonal lattice, } \AA\end{array}$} \\
\hline & & & $a$ & $c$ \\
\hline $\mathrm{Tl}_{5} \mathrm{Te}_{3}$ & 723 & 1130 & $8.9303(3)$ & $12.5987(8)$ \\
\hline $\mathrm{Tl}_{9,8} \mathrm{Gd}_{0,2} \mathrm{Te}_{6}$ & $730-744$ & 1180 & $8.9184(4)$ & $12.6848(9)$ \\
\hline $\mathrm{Tl}_{9.6} \mathrm{Gd}_{0.4} \mathrm{Te}_{6}$ & $740-763$ & 1160 & $8.9064(4)$ & $12.7707(9)$ \\
\hline $\mathrm{Tl}_{9.5} \mathrm{Gd}_{0.5} \mathrm{Te}_{6}$ & $750-770$ & - & - & - \\
\hline $\mathrm{Tl}_{9.4} \mathrm{Gd}_{0.6} \mathrm{Te}_{6}$ & $760-773$ & 1150 & $8.8953(4)$ & $12.8558(8)$ \\
\hline $\mathrm{Tl}_{9.2} \mathrm{Gd}_{0.8} \mathrm{Te}_{6}$ & 775-788; 1100 & 1150 & $8.8824(3)$ & $12.9417(8)$ \\
\hline $\mathrm{Tl}_{9.1} \mathrm{Gd}_{0.9} \mathrm{Te}_{6}$ & 785-793; 1150 & - & - & - \\
\hline $\mathrm{Tl}_{9} \mathrm{GdTe}_{6}$ & $800 ; 1190$ & 1100 & $8,8705(4)$ & $13,0277(7)$ \\
\hline $\mathrm{Tl}_{9} \mathrm{Sb}_{0,2} \mathrm{Gd}_{0,8} \mathrm{Te}_{6}$ & $798 ; 1100$ & 1150 & $8.8616(5)$ & $13.0218(8)$ \\
\hline $\mathrm{Tl}_{9} \mathrm{Sb}_{0,4} \mathrm{Gd}_{0,6} \mathrm{Te}_{6}$ & 795 & 1130 & $8.8536(5)$ & $13.0167(9)$ \\
\hline $\mathrm{Tl}_{9} \mathrm{Sb}_{0,5} \mathrm{Gd}_{0,5} \mathrm{Te}_{6}$ & 794 & - & - & - \\
\hline $\mathrm{Tl}_{9} \mathrm{Sb}_{0,6} \mathrm{Gd}_{0,4} \mathrm{Te}_{6}$ & 793 & 1120 & $8.8454(4)$ & $13.0115(8)$ \\
\hline $\mathrm{Tl}_{9} \mathrm{Sb}_{0,8} \mathrm{Gd}_{0,2} \mathrm{Te}_{6}$ & 792 & 1050 & $8.8373(3)$ & $13.0066(7)$ \\
\hline $\mathrm{Tl}_{9} \mathrm{SbTe}_{6}$ & 790 & 1000 & $8.8315(4)$ & $13.0017(7)$ \\
\hline
\end{tabular}

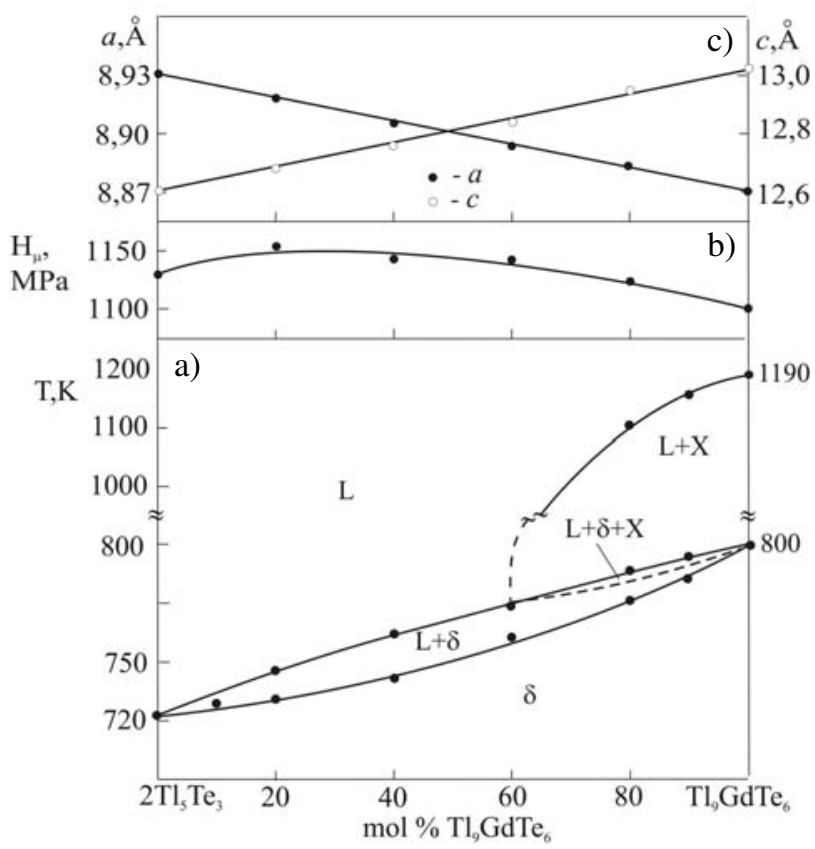

Fig. 1. Polythermal section (a), concentration relations of microhardnesses (b), and lattice parameters (c) for the system $2 \mathrm{Tl}_{5} \mathrm{Te}_{3}-$ $\mathrm{Tl}_{9} \mathrm{GdTe}_{6}$

The curves of microhardness dependencies have a flat maximum, which is typical for systems with continuous solid solutions (Fig. 1b and 2b).

The XRD patterns obtained are presented in Fig. 3. Powder diffraction patterns of $\mathrm{Tl}_{5} \mathrm{Te}_{3}, \mathrm{Tl}_{9} \mathrm{SbTe}_{6}$ and $\mathrm{Tl}_{9} \mathrm{GdTe}_{6}$, and intermediate alloys were very similar to that of $\mathrm{Tl}_{5} \mathrm{Te}_{3}$ with slight reflections displacement from one compound to another. The lattice parameters of solid solutions depend linearly on the composition, i.e. obey the Vegard's rule.

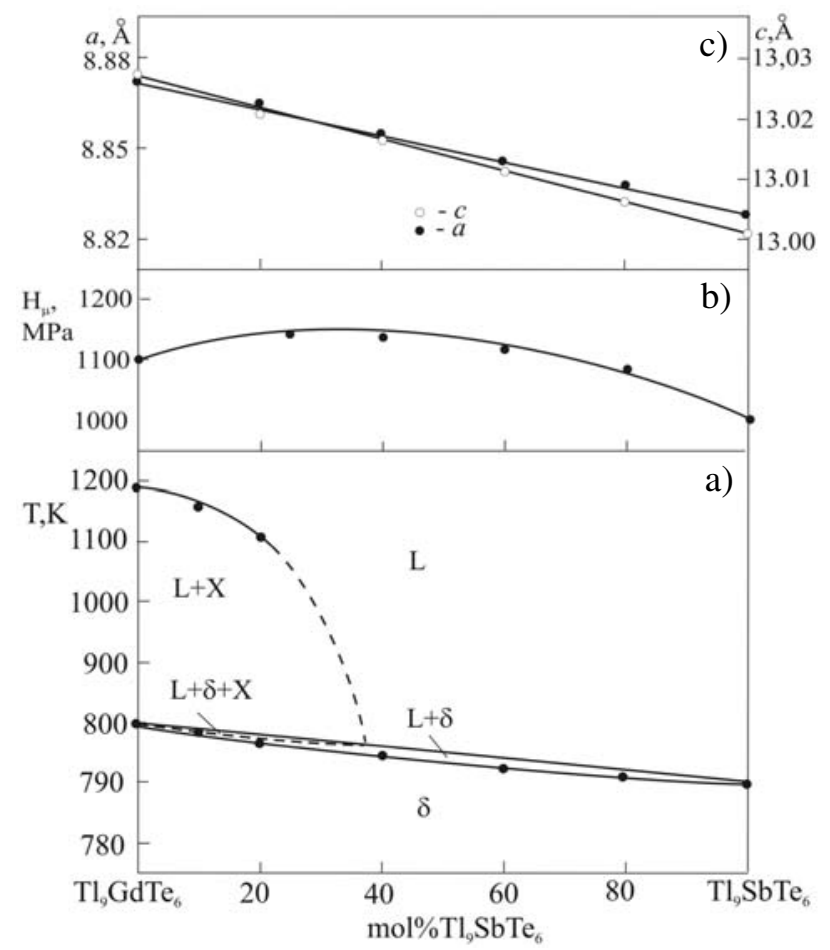

Fig. 2. Polythermal section (a), concentration relations of microhardnesses (b), and lattice parameters (c) for the system $\mathrm{Tl}_{9} \mathrm{GdTe}_{6}$ $\mathrm{Tl}_{9} \mathrm{SbTe}_{6}$

\section{Projections of the liquidus and solidus surfaces of} the $\mathrm{Tl}_{5} \mathrm{Te}_{3}-\mathrm{Tl}_{9} \mathrm{SbTe}_{6}-\mathrm{Tl}_{9} \mathrm{GdTe}_{6}$ system.

Liquidus of the $\mathrm{Tl}_{5} \mathrm{Te}_{3}-\mathrm{Tl}_{9} \mathrm{SbTe}_{6}-\mathrm{Tl}_{9} \mathrm{GdTe}_{6}$ system consists of two fields of the primary crystallization of $\mathrm{X}$-phase and $\delta$ - solid solutions, limited by the ab curve corresponds to the monovariant peritectic $\mathrm{L}+\mathrm{X} \leftrightarrow \delta$ equilibrium (Fig. 4). 




Fig. 3. XRD patterns for different compositions in the $\mathrm{Tl}_{5} \mathrm{Te}_{3}-\mathrm{Tl}_{9} \mathrm{GdTe}_{6}$ (patterns 1-3) and $\mathrm{Tl}_{9} \mathrm{GdTe}_{6}-\mathrm{Tl}_{9} \mathrm{SbTe}_{6}$ (patterns 3-5) systems. 1- $\mathrm{Tl}_{5} \mathrm{Te}_{3}$;

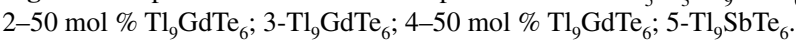

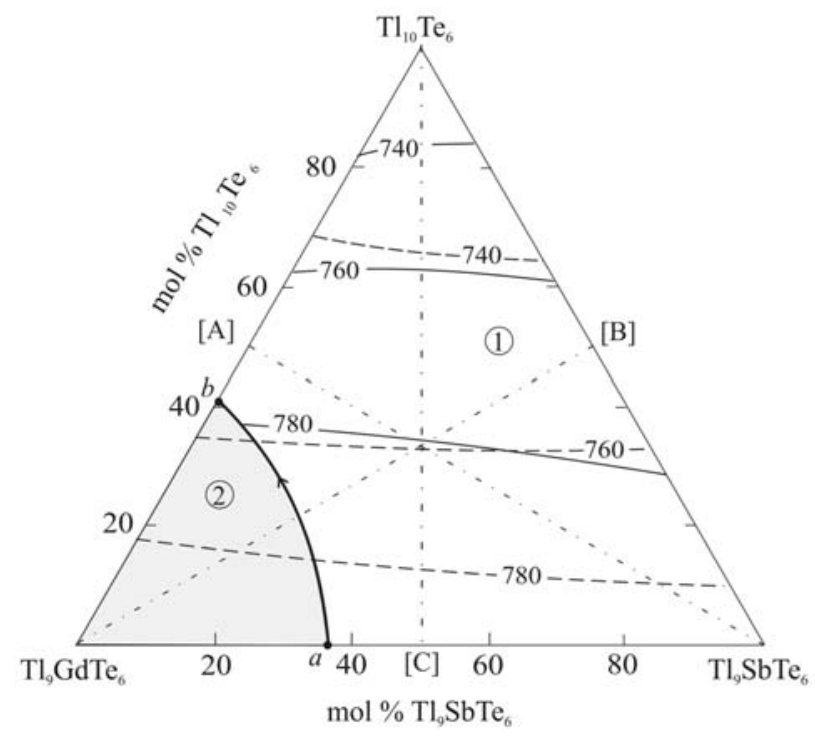

Fig.4. Projections of the liquidus and solidus (dashed lines) surfaces of the $\mathrm{Tl}_{5} \mathrm{Te}_{3}-\mathrm{Tl}_{9} \mathrm{GdTe}_{6}-\mathrm{Tl}_{9} \mathrm{SbTe}_{6}$ system. Dash-dot lines show the investigated sections. Primary crystallization phases: $1-\delta ; 2-X$ phase.

Isopleth sections of the $\mathrm{Tl}_{5} \mathrm{Te}_{3}-\mathrm{Tl}_{9} \mathrm{SbTe}_{6}-\mathrm{Tl}_{9} \mathrm{GdTe}_{6}$ system (Fig.5).

Figs. 5a-c show the isopleth sections $2 \mathrm{Tl}_{5} \mathrm{Te}_{3}-[\mathrm{C}]$, $\mathrm{Tl}_{9} \mathrm{SbTe}_{6}-[\mathrm{A}]$ and $\mathrm{Tl}_{9} \mathrm{GdTe}_{6}-[\mathrm{B}]$ of the $\mathrm{Tl}_{5} \mathrm{Te}_{3}-\mathrm{Tl}_{9} \mathrm{SbTe}_{6}-$
$\mathrm{Tl}_{9} \mathrm{GdTe}_{6}$ system, where $\mathrm{A}, \mathrm{B}$ and $\mathrm{C}$ are equimolar compositions of the boundary systems as shown in Fig. 4.

According to the phase diagram of the $\mathrm{Tl}_{9} \mathrm{GdTe}_{6}$ [B] cut, the primary crystallization of the $\delta$-phase occurs from the liquid phase in the composition area $<60 \mathrm{~mol} \%$ $\mathrm{Tl}_{9} \mathrm{GdTe}_{6}$. In the $\mathrm{Tl}_{9} \mathrm{GdTe}_{6}$ - rich alloys the X-phase first crystallizes, then a monovariant peritectic equilibrium $\mathrm{L}+$ $\mathrm{X} \leftrightarrow \delta$ takes place.

As can be seen, over the entire compositions area of the $\mathrm{Tl}_{9} \mathrm{SbTe}_{6}-[\mathrm{A}]$ and $\mathrm{Tl}_{5} \mathrm{Te}_{3}$-[C] cuts only $\delta$-phase crystallizes from the melt.

Comparison between isopleth sections (Fig. 5) with the isothermal section (Fig. 6) shows, that tie-lines positions in two-phase area $\mathrm{L}+\delta$ do not correspond to the cross section planes and continuously change with temperature. The tie-lines positions at $760 \mathrm{~K}$ are shown in Fig. 6.

\section{Conclusion}

A T-x-y diagram of the $\mathrm{Tl}_{5} \mathrm{Te}_{3}-\mathrm{Tl}_{9} \mathrm{SbTe}_{6}-\mathrm{Tl}_{9} \mathrm{GdTe}_{6}$ system, including the phase diagrams of boundary systems $\mathrm{Tl}_{5} \mathrm{Te}_{3}-\mathrm{Tl}_{9} \mathrm{TbTe}_{6}$ and $\mathrm{Tl}_{9} \mathrm{SbTe}_{6}-\mathrm{Tl}_{9} \mathrm{TbTe}_{6}$, isothermal section at $760 \mathrm{~K}$, some isopleth sections and also the liquidus and solidus surfaces projections, were constructed. 

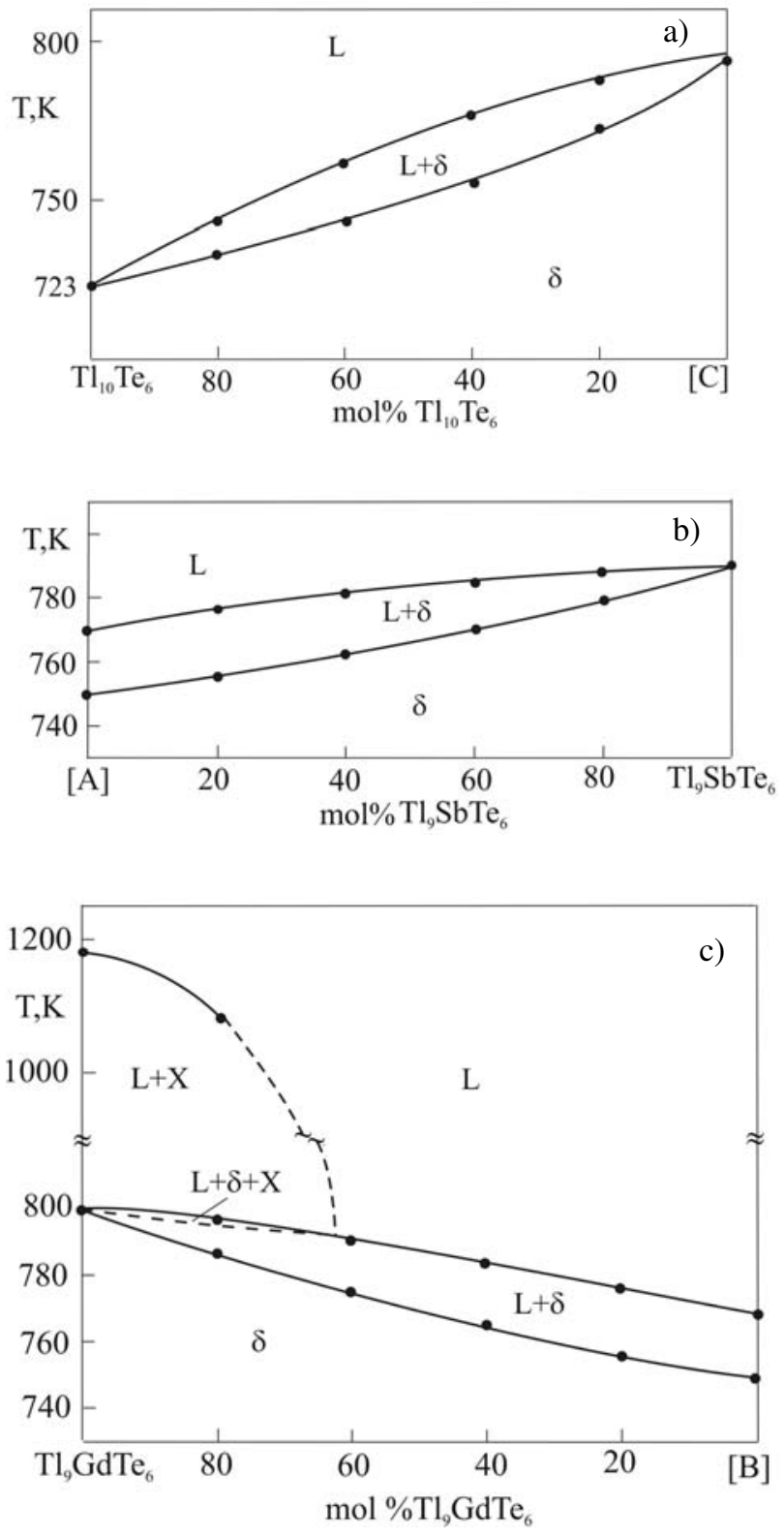

Fig. 5. Polythermal sections $\mathrm{Tl}_{10} \mathrm{Te}_{6}-[\mathrm{C}], \mathrm{Tl}_{9} \mathrm{SbTe}_{6}-[\mathrm{A}]$, and $\mathrm{Tl}_{9} \mathrm{GdTe}_{6}-[\mathrm{B}]$ of the phase diagram of the $\mathrm{Tl}_{5} \mathrm{Te}_{3}-\mathrm{Tl}_{9} \mathrm{SbTe}_{6}-$ $\mathrm{Tl}_{9} \mathrm{GdTe}_{6}$ system.

Components of the system display unlimited solubility in the solid state. Obtained experimental data can be used for choice the composition of solution-melt and for determining of temperature conditions for growing crystals of $\delta$ phase with a given composition.

\section{Acknowledgment}

This work was done in the international joint research laboratory between Institute of Catalysis and Inorganic Chemistry of ANAS (Azerbaijan) and Donostia International Physics Center (Basque Country, Spain).

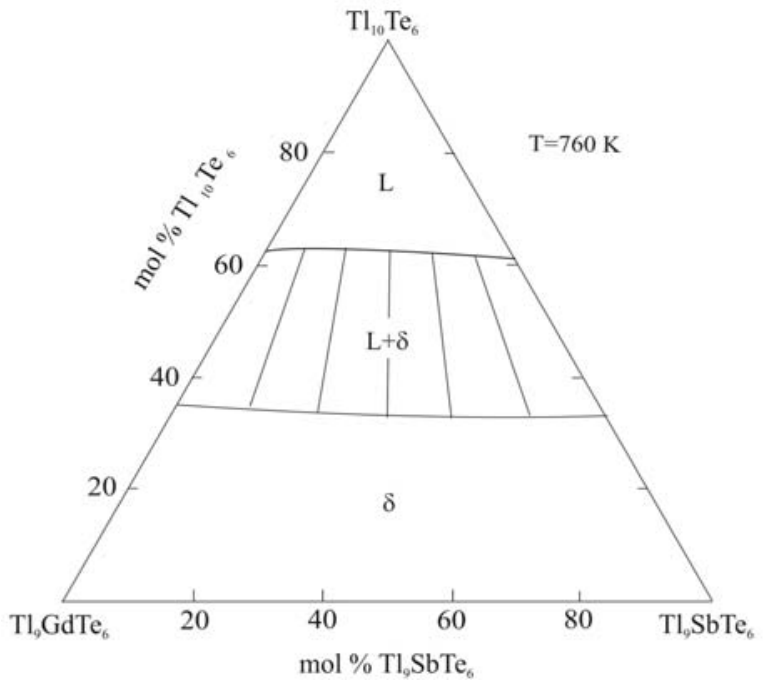

Fig.6. The isothermal section of the phase diagram at $760 \mathrm{~K}$ of the $\mathrm{Tl}_{5} \mathrm{Te}_{3}-\mathrm{Tl}_{9} \mathrm{GdTe}_{6}-\mathrm{Tl}_{9} \mathrm{SbTe}_{6}$ system.

\section{References}

1. Applications of Chalcogenides: S, Se, and Te, ed. by Gurinder Kaur Ahluwalia, Springer, 2016.

2. A. R. Jha, Rare Earth Materials: Properties and Applications, CRC Press, United States, 2014.

https://doi.org/10.1201/b17045

3. CRC Handbook of Thermoelectrics, ed. by D. M. Rowe, CRC Press, New York, 1995.

4. B. Yan, H-J.Zhang, C-X.Liu, X-L. Qi, T. Frauenheim and S-C. Zhang, Phys. Rev. B. 2010, 82, 161108(R)-7

5. N. Singh and U. Schwingenschlogl, Phys. Status Solidi RRL. 2014, 8, 805-808. https://doi.org/10.1002/pssr.201409110

6. I. Schewe, P. Böttcher, H. G. Schnering, Z. Kristallogr. 1989, Bd188, 287-298. https://doi.org/10.1524/zkri.1989.188.3-4.287

7. M. B. Babanly, A. Azizulla, A. A. Kuliev, Russ. J. Inorg. Chem. 1985, 30, 1051-1059.

8. M. B. Babanly, A. Azizulla, A. A. Kuliev, Russ. J. Inorg. Chem. 1985, 30, 2356-2359.

9. A. A. Gotuk, M. B.Babanly, A. A. Kuliev, Inorg. Mater. 1979, 15, 1062-1067.

10. K. Kurosaki, H. Uneda, H. Muta and S. Yamanaka, J. Alloys Compd. 2004, 376, 43-48. https://doi.org/10.1016/j.jallcom.2004.01.018

11. Q. Guo, A. Assoud, H. Kleinke. Adv.Energy Mater. 2014, 4, 1400348/1-8.

12. B. Wolfing, C. Kloc, J. Teubner, E. Bucher, Phys. Rev. Let. 2001, 36, 4350-4353. https://doi.org/10.1103/PhysRevLett.86.4350

13. K. E. Arpino, D. C.Wallace, Y. F. Nie, T. Birol, P. D. C. King, S. Chatterjee, M. Uchida, S. M. Koohpayeh, J.-J. Wen, K. Page, C. J. Fennie, K. M.Shen, and T. M. McQueen, Phys. Rev. Lett. (PRL). 2014, 112, 017002-5. https://doi.org/10.1103/PhysRevLett.112.017002 
14. S. Z. Imamalieva, F. M. Sadygov, M. B. Babanly, Inorg. Mater. 2008, 44, 935-938. https://doi.org/10.1134/S0020168508090070

15. M. B. Babanly, S. Z. Imamaliyeva, D. M. Babanly, Azerb. Chem. J. 2009, 2, 121-125.

16. M. B. Babanly, S. Z. Imamaliyeva, F. M. Sadygov, News of BSU. Nat. Sci. Ser. 2009, 4, 5-10.

17. S. Bangarigadu-Sanasy, C. R. Sankar, P. Schlender, H. Kleinke, J. Alloys Compd. 2013, 549, 126-134. https://doi.org/10.1016/j.jallcom.2012.09.023

18. S. Bangarigadu-Sanasy, C. R. Sankar, P. A. Dube, J. E. Greedan, H. Kleinke, J. Alloys. Compd. 2014, 589, 389-392. https://doi.org/10.1016/j.jallcom.2013.11.229

19. Q. Guo, H. Kleinke, J. Alloys. Compd. 2015, 630, 37-42. https://doi.org/10.1016/j.jallcom.2015.01.025
20. M. B. Babanly, J.-C. Tedenac, S. Z. Imamalieva, F. N. Guseynov, G. B. Dashdieva, J. Alloys Compd. 2010, 491, 230236. https://doi.org/10.1016/j.jallcom.2009.08.157

21. S. Z. Imamaliyeva, F. N. Guseynov, M. B. Babanly, J. Chem. Probl. 2008, 4, 640-646.

22. S. Z. Imamaliyeva, F. N. Guseynov, M. B. Babanly, Azerb. Chem.J. 2009, 1, 49-53.

23. M. M. Asadov, M. B. Babanly, A. A. Kuliev, Inorg. Mater. 1977, 13, 1407-1410.

24. S. Z. Imamaliyeva, T. M. Gasanly, I. R. Amiraslanov, M. B. Babanly, Austr. J. Basic Appl. Sci. 2015, 9, 541.

25. K. Wacker, Kristallogr. Supple. 1991, 3, 281.

26. C. R. Sankar, S. Bangarigadu-Sanasy, H. Kleinke, J. El. Mater. 2012, 41, 1662-1266.

\section{Povzetek}

$\mathrm{V}$ sistemu $\mathrm{Tl}_{5} \mathrm{Te}_{3}-\mathrm{Tl}_{9} \mathrm{SbTe}_{6}-\mathrm{Tl}_{9} \mathrm{GdTe}_{6}$ smo preučevali fazna ravnotežja s termično analizo, rentgensko praškovno difrakcijo in meritvami mikrotrdote. Pripravili smo nekatere izopletne in izotermične krivulje pri $760 \mathrm{~K}$ ter projekcije tekočinsko trdnih površin. V tem sistemu smo našli serijo kontinuirnih trdnih raztopin. Trdne raztopine kristalizirajo v tetragonalnem $\mathrm{Tl}_{5} \mathrm{Te}_{3}$ kristalnem sistemu. 